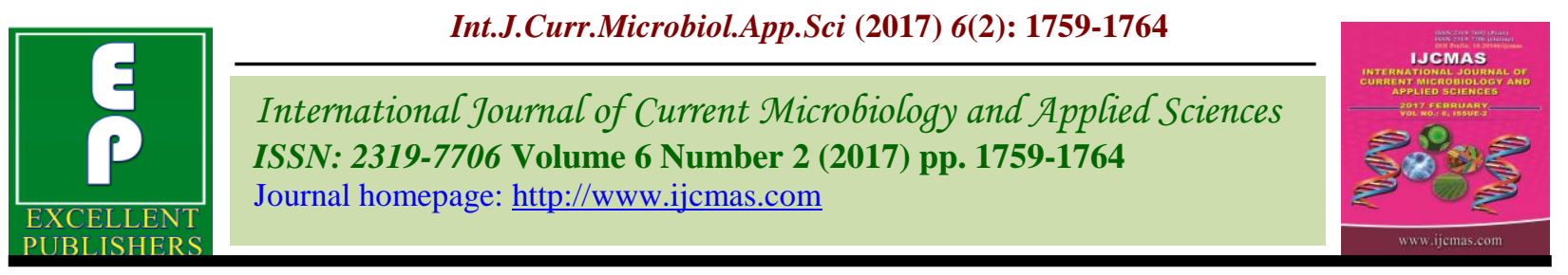

Original Research Article

http://dx.doi.org/10.20546/ijcmas.2017.602.197

\title{
Morpho-Physiological Traits and Productivity on Garden Pea (Pisum sativum L.) As Influenced by Various Methods of Application of Potassium Humate 4.5
}

\author{
Dhanraj Patel $^{1}$, J.P.Mehra ${ }^{1}$, D. Malviya ${ }^{1}$, Sandeep Singh $^{2} *$ and B.R.Baraiya ${ }^{1}$ \\ ${ }^{1}$ Department of Plant Physiology, College of Agriculture, J.N.K.V.V, \\ Jabalpur (M.P.)-482 004, India \\ ${ }^{2}$ Food Corporation of India, Regional Office, Patna-800001, India \\ *Corresponding author
}

\section{A B S T R A C T}

\begin{tabular}{|l|}
\hline K e y w o r d s \\
Garden pea, \\
Morpho- \\
physiological traits, \\
Yield attributes, \\
Yield.
\end{tabular}

The field experiment was laid out in randomized block design with three replications to investigate the morpho-physiological traits and productivity of garden pea (Pisum sativum L. as influenced by the application of potassium humate. The experiment consisted seven treatment combinations and each treatment has common used of potassium humate 4.5 @ 5 lit/acre before basal dose of manure/fertilizers, which denoted by SA- Soil application, FA- foliar application and FA- foliar spray, described as $\mathrm{T}_{1}$ - control, $\mathrm{T}_{2}-\mathrm{SA}+\mathrm{FS} @ 5: 250$ of water after one month of $1^{\text {st }}$ application, $\mathrm{T}_{3}-\mathrm{SA}+2^{\text {nd }} \mathrm{SA} @$ 5:150 after one month of FA, $\mathrm{T}_{4^{-}} \mathrm{SA}+\mathrm{FS} @$ 5:250 after 45 days of $1^{\text {st }}$ application, $\mathrm{T}_{5^{-}} \mathrm{SA}+\mathrm{SA} @$ 5: $150+$ after 30 days of $1^{\text {st }}$ application + FA @ 3: 150 after 45 days of $2^{\text {nd }}$ application, $\mathrm{T}_{6}-\mathrm{SA}+\mathrm{FS} @ 5: 250$ immediately after $1^{\text {st }}$ picking and $\mathrm{T}_{7^{-}} \mathrm{SA}+\mathrm{FS} @$ 5: 250 after 15 days of $1^{\text {st }}$ picking during rabi 2014-15. Among the different treatment combinations, $\mathrm{T}_{5}$ had showed significant difference during phenophasic period except emergence and tendril formation, resulted highest yield attributing characters like number of nodes/ plant, filled pods/ plant (20.83), Seeds/ pod (4.51), pod length, green pod yield/ plant and seed yield (18.31 g/ plant \& $20.38 \mathrm{qtl} / \mathrm{ha}$ ) of garden pea over control; while, it was remained at par in terms of biological yield (41.55 qtl/ha) from $\mathrm{T}_{4}$ (42.05 qtl/ha). The maximum harvest index recorded under $\mathrm{T}_{3}$. Moreover, seed index was found to be non-significant but maximum with other treatments.

\section{Introduction}

Garden pea (Pisum sativun L.) belongs to the family Leguminoceae which is comprised of three subfamilies and approximately 15,000 species that exhibit diverse morphology habitat and ecology (Denarie et al., 1992). Pea is an important rabi pulse crop of India and known as common name Mater (Hindi, Nepali) Pea; Field pea, Split pea, Garden pea, Seed pea, Shelling pea, Combining pea, Forage or Fodder pea, Dry pea, Feed pea,
Vining pea (English). Pea was among the first crop cultivated by man who is highly productive grown for food, forage and vegetable. Pea is an important frost-hardy, cool season, nutritious leguminous vegetable that is widely cultivated throughout the world. It is a rich source of protein, amino acids, sugars, carbohydrates, vitamins $\mathrm{A}$ and $\mathrm{C}$, calcium and phosphorus, besides having a small quantity of iron. Garden peas being 
erect, remains erect while field peas have a tendency to climb when provided with a support. Plants bear tap root system with nodules on the surface. Stems are hollow, slender, succulent and ridged. It bears pinnately compound leaves with 3 pairs of leaflets and terminals are modified into branched tendril. Potassium humate is a complete organic molecule formed by the breakdown of organic matter in soil by microorganisms and it is not a fertilizer. It is found in forest soil 2\%-3\% and rich in oxidized low rock coal, lignite, peat etc., major constituents of carbon and oxygen about 90\%. Using potassium humate has a variety of benefits and it is applicable for all type of crops. Our land lost its fertility due-to prolonged and excess use of chemical fertilizers and pesticides. It improves physical property of soil, ion exchange capacity, water holding capacity and drought tolerance ability. This also prevents loss of nutrients from soil and act as a store house by keeping plant nutrients in soil. It increases crop yield and reduces the use of pesticide and chemical fertilizers. Our Indian soils are low in organic carbon. Due to intensive cultivation, organic matter and other nutrients are depleted from the soil. To compensate this, traditionally organic manure, compost, vermi compost and green manure are used in large quantities to achieve humic acid content in the soil. Application of potassium humate helps to build up organic matter content in the soil, enhancing water retention, cation exchange capacity, plant growth stimulant and helps to improve the yield of crops. Therefore the application of humate was tested as an approach to improve both the nutrient balance and plant vitality (Boehme et al., 2005). Foliar sprays of these substances also promote growth, increases yield and quality in a number of plant species (Yildirim, 2007; Karakurt et al., 2009). Applications of humic substances (HS) may help in achieving of increasing organic food production as HS applications are generally recommended in organic agriculture (Shahryari et al., 2009). Therefore, an experiment was conducted to study the effect of various methods of potassium humate 4.5 applications on morpho-physiological traits and productivity of garden pea.

\section{Materials and Methods}

A field experiment was conducted at the Experimental area, Department of plant physiology, JNKVV, Jabalpur (M.P.) during Rabi Season of 2014-15. The soil of the experimental field was sandy clay loam in texture, slightly alkaline in reaction $(\mathrm{pH} 7.5)$, low in available nitrogen (245 $\mathrm{Kg} / \mathrm{ha})$ and phosphorus $(7.99 \mathrm{Kg} / \mathrm{ha})$ as well as medium in available potassium $(348 \mathrm{Kg} / \mathrm{ha})$ contents. The experiment was laid out in randomized block design, consisting total 7 treatments with 3 replications. A combination of 7 treatments viz. $\mathrm{T}_{1}$ (only normal package of practices without application of potassium humate (control) $\mathrm{T}_{2}$ (Soil application of potassium humate 4.5@ 5 liter/acre before the basal dose of manure/fertilizer+ foliar spray of potassium humate 4.5 @ 5 liter in 250 liter of water after one month of $1^{\text {st }}$ application), $\mathrm{T}_{3}$ (Soil application of potassium humate $4.5 @ 5$ liter/acre before the basal dose of manure/ fertilizer $+2^{\text {nd }}$ soil application 5 liter with 150 liter of water one month of the first application), $\mathrm{T}_{4}$ (Soil application of potassium humate 4.5 @ liter/acre before the basal dose of manure /fertilizer + foliar spray of potassium humate 4.5 @ 5 liter in 250 liter of water after 45 days of $1^{\text {st }}$ application), $\mathrm{T}_{5}$ (Soil application of potassium humate 4.5@ 5 liter/ acre before the basal dose of manure/fertilizer + soil application of potassium humate $4.5 @$ 5 liter in 150 litter of water + after 30 days of first application + foliar spray of potassium humate $4.5 @ 3$ liter in 150 litter of water after 45 days of $2^{\text {nd }}$ application), $\mathrm{T}_{6}$ (Soil application of potassium humate $4.5 @ 5$ liter/acre before the basal dose of manure/ 
fertilizer + foliar spray of potassium humate $4.5 @ 5$ liter in 250 liter of water immediately after $1^{\text {st }}$ picking) and $\mathrm{T}_{7}$ (Soil application of potassium humate $4.5 @ 5$ liter/acre before the basal dose of manure/fertilizer + foliar spray of potassium humate $4.5 @ 5$ liter in 250 liter of water after 15 days of $1^{\text {st }}$ picking). The seeds were treated with carbendazim $2.5 \mathrm{~g} / \mathrm{kg}$ of seeds and rhizobium leguminosarum $10 \mathrm{~g} / \mathrm{kg}$ of seeds. Sowing of garden pea seeds was done on $8^{\text {th }}$ November 2014 by hand dibbling. The Seeds @ $100 \mathrm{Kg} / \mathrm{ha}$ in rows 30 $\mathrm{cm}$ apart. Nitrogen, Phosphorus and potassium were applied at $30: 70: 40 \mathrm{Kg} / \mathrm{ha}$ NPK respectively in each lot. Irrigation was applied after sowing 1, 17, 35 and 53 days after sowing. The phenological changes were recorded through visual observations and sampling to analyze the dry matter production and partitioning efficiencies. The physiological traits and mechanisms viz., quantum efficiency, carboxylation efficiency, water use efficiency, mesophyll efficiency, canopy temperature, net photosynthetic rate and transpiration rate were measured by using infrared gas analyzer (IRGA). The observations were recorded on plant height (cm), number of nodes/plant, number of pods/plant, number of seeds/pod, number of filled pods/plant, 100- seed weight $(\mathrm{g})$, Pod length $(\mathrm{cm})$, pod width $(\mathrm{mm})$, pod girth $(\mathrm{mm})$, green pod yield (g/plant), seed yield (g/plant, $\mathrm{Kg} / \mathrm{ha}$ ), biological yield (g/plant and qtl/ha) and harvest index (\%). The data were analyzed by using the 'Analysis of variance Technique' as per the procedures described by Synder and Corlson (1967). The treatment means were compared at $5 \%$ level of significance.

\section{Results and Discussion}

\section{Marpho-physiological traits in garden pea}

During the present study, the different treatments combination significantly influenced the morpho-physiological characters, and $\mathrm{T}_{5}$ was recorded nonsignificantly earlier days to emergence than $\mathrm{T}_{4}$, regardless to the application of $\mathrm{T}_{6}$ treatment over control. Whether days to 2 to 4 leaf stage (10.33), flower initiation (34.67), $50 \%$ of flowering (39.33), pod initiation (41.33), seed formation (49.33), first picking (74.67), physiological maturity (103.67) and physical maturity (109.33) was lower than $\mathrm{T}_{1}$, $\mathrm{T}_{2}, \mathrm{~T}_{3}$ and $\mathrm{T}_{4}$ during experimentation; while, the treatment $T_{6}$ and $T_{7}$ were shown in very earlier day over all the treatment for all respective characters. The early seedling emergence has the advantage of attaining the longer crop duration which may have better chances of producing early leaf formation and higher economic yield due to quit longer period of solar energy interception. The $T_{7}$ recorded in minimum days of time to attaining this stage. Whereas, days to $1^{\text {st }}$ flower initiation exhibited significantly more time in $\mathrm{T}_{1}$ (35.67) to acquire this stage than $\mathrm{T}_{6}$ and $\mathrm{T}_{7}$ and remained at par to $\mathrm{T}_{2}, \mathrm{~T}_{3}, \mathrm{~T}_{4}$ and $\mathrm{T}_{5}$ (34.67), respectively.

The flower initiation is an important phenological phases which determines the plant productivity in pigeonpea (Bhattacharya and Sharma, 2001). The significant correlation of early days to flower initiation with yield would be effective for improving in green pod yield in garden pea (Kumar et al., 2008) and high positive significant correlation of days to first picking with nod number was noted at which first flower appears observed by Sharma and Sharma (2012). Similarly, $\mathrm{T}_{7}$ took minimum time (38.33 days) and maximum in $\mathrm{T}_{1}$ to attain this stage (Table 1 ).

However, in days to pod initiation significantly in $\mathrm{T}_{6}$ recorded minimum days than $\mathrm{T}_{1}$ taken longer period. But $\mathrm{T}_{5}$ was remained at par to $T_{7}$ who closed to $T_{6}$ in study and $\mathrm{T}_{7}$ resulted early seed formation. 
Table.1 Various phenophases of garden pea under various treatments during crop growth period

\begin{tabular}{|c|c|c|c|c|c|c|c|c|c|c|}
\hline Treatments & $\begin{array}{c}\text { Days to } \\
\text { seedling } \\
\text { emergence }\end{array}$ & $\begin{array}{c}\text { Days to } 2 \\
\text { to } 4 \text { leaf } \\
\text { stage }\end{array}$ & $\begin{array}{c}\text { Days to } \\
\text { tendril } \\
\text { formation }\end{array}$ & $\begin{array}{c}\text { Days to } \\
1^{\text {st }} \text { flower } \\
\text { initiation }\end{array}$ & $\begin{array}{c}\text { Days to } 50 \\
\% \\
\text { flowering }\end{array}$ & $\begin{array}{c}\text { Days to } \\
\text { pod } \\
\text { initiation }\end{array}$ & $\begin{array}{c}\text { Days to } \\
\text { seed } \\
\text { formation }\end{array}$ & $\begin{array}{c}\text { Days to } \\
1^{\text {st }} \\
\text { picking }\end{array}$ & $\begin{array}{c}\text { Days to } \\
\text { Physiologic } \\
\text { al maturity }\end{array}$ & $\begin{array}{c}\text { Days to } \\
\text { physical } \\
\text { maturity }\end{array}$ \\
\hline $\mathrm{T}_{1}$ & 4.33 & 12.00 & 15.67 & 35.67 & 41.67 & 43.33 & 50.67 & 75.33 & 105.33 & 111.33 \\
\hline $\mathrm{T}_{2}$ & 4.67 & 10.67 & 15.67 & 34.67 & 40.33 & 41.67 & 50.33 & 76.33 & 105.67 & 111.33 \\
\hline $\mathrm{T}_{3}$ & 4.67 & 10.67 & 16.00 & 35.33 & 40.33 & 41.67 & 50.00 & 78.33 & 105.67 & 111.33 \\
\hline $\mathrm{T}_{4}$ & 5.00 & 11.00 & 16.00 & 35.00 & 40.33 & 42.00 & 49.67 & 79.33 & 106.00 & 111.33 \\
\hline $\mathrm{T}_{5}$ & 4.00 & 10.33 & 15.67 & 34.67 & 39.33 & 41.33 & 49.33 & 74.67 & 103.67 & 109.33 \\
\hline $\mathrm{T}_{6}$ & 4.33 & 10.00 & 15.67 & 33.67 & 38.33 & 40.00 & 47.00 & 70.00 & 100.67 & 108.00 \\
\hline $\mathrm{T}_{7}$ & 4.67 & 10.00 & 15.67 & 33.00 & 38.33 & 40.33 & 47.00 & 68.00 & 100.67 & 106.33 \\
\hline SEm \pm & 0.3 & 0.395 & 0.552 & 0.36 & 0.35 & 0.39 & 0.747 & 1.007 & 0.733 & 0.707 \\
\hline CD 5\% & - & 1.217 & - & 1.12 & 1.06 & 1.21 & 2.302 & 3.102 & 2.258 & 2.179 \\
\hline
\end{tabular}

Table.2 Yield and yield contributing attributes in different treatments in garden pea

\begin{tabular}{|c|c|c|c|c|c|c|c|c|c|c|c|c|c|c|c|}
\hline \multirow{2}{*}{ Treatments } & \multirow{2}{*}{ I } & \multirow{2}{*}{ II } & \multirow{2}{*}{ III } & \multirow{2}{*}{ IV } & \multirow{2}{*}{$\mathbf{V}$} & \multirow{2}{*}{ VI } & \multirow{2}{*}{ VII } & \multirow{2}{*}{ VIII } & \multirow{2}{*}{ IX } & \multirow{2}{*}{$\mathbf{X}$} & \multicolumn{2}{|l|}{ XI } & \multicolumn{2}{|l|}{ XII } & \multirow{2}{*}{ XIII } \\
\hline & & & & & & & & & & & (a) & (b) & (a) & (b) & \\
\hline $\mathrm{T}_{1}$ & 81.87 & 15.07 & 14.80 & 14.27 & 3.83 & 23.55 & 6.90 & 9.60 & 3.20 & 59.69 & 10.53 & 16.60 & 23.41 & 36.60 & 45.47 \\
\hline $\mathrm{T}_{2}$ & 78.80 & 16.13 & 16.73 & 15.93 & 4.23 & 23.75 & 7.23 & 9.92 & 3.31 & 68.23 & 13.37 & 19.16 & 25.17 & 38.20 & 50.36 \\
\hline $\mathrm{T}_{3}$ & 74.67 & 16.13 & 16.00 & 15.20 & 4.26 & 23.47 & 7.21 & 10.37 & 3.46 & 65.52 & 12.40 & 18.91 & 19.90 & 33.52 & 56.41 \\
\hline $\mathrm{T}_{4}$ & 73.87 & 21.67 & 21.53 & 20.80 & 4.49 & 24.44 & 7.43 & 10.19 & 3.40 & 75.30 & 16.79 & 19.87 & 34.22 & 42.05 & 47.30 \\
\hline $\mathrm{T}_{5}$ & 77.07 & 22.30 & 21.40 & 20.83 & 4.51 & 24.46 & 7.81 & 10.58 & 3.53 & 105.04 & 18.31 & 20.38 & 29.53 & 41.55 & 49.05 \\
\hline $\mathrm{T}_{6}$ & 81.47 & 16.67 & 15.60 & 15.07 & 4.11 & 23.47 & 7.59 & 10.86 & 3.62 & 61.68 & 12.16 & 17.70 & 23.50 & 37.35 & 47.47 \\
\hline $\mathrm{T}_{7}$ & 77.87 & 20.53 & 18.93 & 18.33 & 4.32 & $23 . .83$ & 7.35 & 10.83 & 3.61 & 70.87 & 14.89 & 19.25 & 27.48 & 38.26 & 50.54 \\
\hline SEm \pm & 1.22 & 1.03 & 0.93 & 0.98 & 0.08 & 0.22 & 0.11 & 0.17 & 0.31 & 3.05 & 0.84 & 0.36 & 1.48 & 1.24 & 1.94 \\
\hline CD 5\% & 3.77 & 3.16 & 2.87 & 3.01 & 0.24 & - & 0.33 & 0.53 & - & 9.39 & 2.59 & 1.12 & 4.56 & 3.82 & 5.98 \\
\hline
\end{tabular}

Remarks - I- Plant height (cm), II- No. of nodes /plant, III- No. of pods/ plant, IV- No. of filled pods/ plant, V- No. of seeds/ pod, VI-100 seeds weight (g), VIIPod length (cm), VIII- Pod width (mm), IX- Pod girth (mm), X- Green pod yield (g/plant), XI (a) - Seed yield ( g/plant) and (b)- in qtl/ha, XII (a)- Biological yield (g/plant) and (b)- in qtl/ha, XIII- Harvest index (\%). 
It's might be due to longer duration of pod set provides the optimum time to the pod for its extension which facilitates seed to expend conveniently without mechanical resistance provided by pod, of which $\mathrm{T}_{5}, \mathrm{~T}_{4}, \mathrm{~T}_{3}, \mathrm{~T}_{2}$ and $\mathrm{T}_{1}$ were remained at and on par to each other in sequences. Similar result was also seen in $\mathrm{T}_{5}$ at third position after $\mathrm{T}_{7}$ and $\mathrm{T}_{6}$, respectively in days to $1^{\text {st }}$ picking, physiological maturity and physical maturity. While $T_{6}$ and $T_{7}$ were found to be statistically similar to each other and same pattern also exist in $T_{2}$ and $T_{3}$ in physiological maturity; and $\mathrm{T}_{1}, \mathrm{~T}_{2}, \mathrm{~T}_{3}$ and $\mathrm{T}_{4}$ in physical maturity.

\section{Effect of treatments on yield attributes and yields of garden pea}

During the present study, plant height, number of nodes/plant, pods/plant, filled pods/plant, seeds/pod, pod length, pod width, green pod yield/plant, seed yield, biological yield and harvest index were found to be significant during experimentation. Among the treatment for respective traits, $\mathrm{T}_{5}$ was shown outstanding characters by taking minimum days to attain plant height caused to significantly develop more pods/plant (22.30), filled pods/ plant (20.83), seeds/pod (4.51), pod length (7.81) and got highest green pod yield (105.04 gm) and seed yield (18.31 gm/ plant and $20.38 \mathrm{qtl} / \mathrm{ha}$ ) over all the treatments except $\mathrm{T}_{4}$, which was remained at par over in terms of I, II, IV, V, VI, VII, XI (a) and (b) during experimentation (Table- 2). However, the minimum qualitative traits observed under $\mathrm{T}_{1}$. The higher number of nodes increases more chances of pod sifting which may results in production of higher number of pods which contributes directly to the economic productivity. The humic acid application@3 kg/ha significantly resulted in higher number of pods/plant in moong bean (Muhammad et al., 2014). The higher number of seeds/pod appeared to have contributed remarkably in increasing the economic yield due to its direct involvement as sink component reported by Kumar et al., (2013). While pod length was major yield contributing character and helped in improving the seed yield of garden pea (Katore and Navale, 2010). The number of pods/plant and number of seeds/pod were positively correlated with pod length (Kumar et al., 2014). The green pod yield/plant had the highest positive direct effect of green pod yield in pea (Sarnik et al., 1990). The highest biological yield and harvest index were notified significantly under $T_{4}$ and $T_{3}$, respectively over all treatment except $T_{5}$ in biological yield (41.55 qtl/ha). The lower economic yield in these treatments despite of higher harvest index may be attributed to the low mobilization of photo assimilates to the economic sinless of the plant and $\mathrm{T}_{1}$ recorded lowest harvest index.

\section{References}

Bhattacharya, A. and Sharma, D.K. 2001. Flower drop in pigeon pea: Effect of Physiological traits Sunder normal and late seedling. Legume Res., 24(4): 231237.

Boehme, M., Schevtschenko, J. and Pinker, I. 2005. Iron Supply of Cucumbers in Substrate Culture with Humate. Acta Horticulture, 697 ISHS, 41(1): 329-335.

Denarie, J., Debelle, F. and Rosenberg, C. 1992. Signaling and host range variation in nodulation. Annual Rev. Microbiol., 46: 497-531.

Karakurt, Y., Unlu, H. and Padem, H. 2009. The influence of foliar and soil fertilization of humic acid on yield and quality of pepper. Acta Agriculturae Scandinavica Section B Plant Soil Sci., 59(3): 233-237.

Katore, T.D. and Navale, P.A. 2010. Direct and indirect influence of component characters on yield in pea (Pisum sativum L.). J. Maharashtra Agri. 
Univ., 35(2): 300-302.

Kumar, B., Kumar, A., Singh, A.K. and Lavanya, G.R. 2013. Selection strategy for seed yield and maturity in field pea (Pisum sativum L. arvense). African J. Agri. Res., 8(44): 5411-5415.

Kumar, K., Singh, K. and Mehta, A.K. 2008. Correlation and path coefficient analysis in garden pea. Haryana J. Horticultural Sci., 37(3/4): 329-332.

Kumar, V., Singh, J. and Srivastava, C.P. 2014. Genetic variability, correlation and path analysis based on seed yield attributes traits in diverse genotypes of pea (Pisum sativum L.). Environ. Ecol., 32(3A): 1019-1024

Muhammad, W., Bashir, A., Muhammad, A., Fazal, M., Khan, A.L., Muhammad, A., Sang-Mo, K., Yoon-Ha, K. and In-Jung, L. 2014. Evaluation of Humic Acid Application Methods for Yield and Yield Components of Mungbean. American J. Plant Sci., 5: 2269-2276.

Sarnaik, D.A., Singh, C.B., Hasija, S.K. and Rao, S.K. 1990. Path analysis of green pod yield components in pea. Research and Development Reporter, 7(1-2): 111114.

Synder, F.W. and Carlson, G.E. 1984. Selecting for partitioning of photosynthetic products in crop. $A d v$. Agronomy, 37: 47-72.

Shahryari, R., Gadimov, A., Gurbanov, E. and Valizade, M. 2009. Applications of potassium humate to wheat for organic agriculture in Iran. (Special issue on organic farming and products.) Asian J. Food and Agro-Industry, 2(Special Issue): S164-S168.

Sharma, B.B. and Sharma, V.K. 2012. Character association and path analysis studies for yield and horticultural traits in garden pea. Environ. Ecol., 30(4A): 1591-1598.

Yildirim, E. 2007. Foliar and soil fertilization of humic acid affect productivity and quality of tomato. Acta Agriculturae Scandinavica Section B-Soil Plant Sci., 57: 182-186.

\section{How to cite this article:}

Dhanraj Patel, J.P.Mehra, D. Malviya, Sandeep Singh and Baraiya, B.R. 2017. Morpho Physiological Traits and Productivity on Garden Pea (Pisum sativum L.) As Influenced by Various Methods of Application of Potassium Humate 4.5. Int.J.Curr.Microbiol.App.Sci. 6(2): 1759-1764. doi: http://dx.doi.org/10.20546/ijcmas.2017.602.197 